\title{
Methylcrotonyl-CoA Carboxylase Deficiency
}

National Cancer Institute

\section{Source}

National Cancer Institute. Methylcrotonyl-CoA Carboxylase Deficiency. NCI Thesaurus.

Code C98674.

An autosomal recessive inherited disorder caused by mutations in the MCCC1 or MCCC2 genes. It is characterized by a deficiency in an enzyme that is involved in the metabolism of proteins that contain leucine. Signs and symptoms range from mild to severe and include feeding difficulties, vomiting, diarrhea, developmental delays, lethargy, seizures and coma. 